\title{
En bloc pancreaticoduodenectomy and right hemicolectomy to treat locally advanced right colon cancer: report of three cases
}

\author{
Pancreaticoduodenectomia e hemicolectomia direita em monobloco para o tratamento do \\ câncer de cólon direito localmente avançado: relato de três casos
}

\author{
Sergio Renato Pais Costa ${ }^{1}$, Sergio Henrique Couto Horta ${ }^{2}$, Alexandre Cruz Henriques ${ }^{3}$. Jaques Waisberg ${ }^{4}$, \\ Manlio Basílio Speranzini ${ }^{5}$
}

\begin{abstract}
Although colorectal tumors are fairly common surgical conditions, 5 to $12 \%$ of these tumors are locally advanced (T4 tumors) upon diagnosis. In this particular situation, the efficacy of en bloc multivisceral resection has been proven. When right-colon cancer invades the proximal duodenum or even the pancreatic head, a challenging dilemma arises due to complexity of the curative surgical procedure. Therefore, en bloc pancreaticoduodenectomy with right hemicolectomy should be performed to obtain free margins. The present study reports three cases of locally advanced right-colon cancer invading the proximal duodenum. All of these cases underwent successful en bloc pancreaticoduodenectomy plus right hemicolectomy, with no death occurrence. Long-term survival was observed in two cases ( 30 and 50 months). In the third case, the patient did not present any recurrence twelve months after surgical treatment. Multivisceral resection with en bloc pancreaticoduodenectomy should be considered for patients who present acceptable risk for major surgery and no distant dissemination. This approach seems justified since the length of postoperative survival is longer in radically ressected groups ( $\mathrm{RO}$ ) than in palliativelly resected groups (R1-2).
\end{abstract}

Keywords: Pancreaticoduodenectomy; Colorectal neoplasms; Colonic neoplasms; Adenocarcinoma; Case reports

\section{RESUMO}

Embora os tumores colorretais sejam afecções cirúrgicas relativamente comuns, 5 a $12 \%$ dos casos são diagnosticados como localmente avançados (Tumores T4). Nessa situação particular, a eficácia da ressecção em monobloco já foi comprovada. Quando tumores do cólon direito invadem o duodeno proximal ou ainda a cabeça do pâncreas, um desafiador dilema é observado devido à complexidade do procedimento cirúrgico curativo. Dessa maneira, uma pancreaticoduodenectomia com hemicolectomia direita em monobloco deve ser realizada para se obterem margens livres. 0 presente artigo relata três casos de tumor de cólon direito localmente avançado com invasão do duodeno proximal. Todos esses casos foram submetidos à pancreaticoduodenectomia e hemicolectomia direita em monobloco de forma bem sucedida e sem mortalidade. Sobrevida em longo prazo foi observada em dois doentes (30 e 50 meses). No terceiro caso, o paciente não apresentava recidiva após 12 meses de seu tratamento cirúrgico. A ressecção multivisceral com pancreaticoduodenectomia em monobloco deve ser considerada em doentes com risco cirúrgico aceitável para cirurgia de grande porte e sem disseminação à distância. Essa conduta permanece justificada, pois a sobrevida a longo prazo dos doentes submetidos à ressecção radical (R0) é mais longa do que daqueles cuja ressecção é paliativa (R1-2).

Descritores: Pancreaticoduodenectomia; Neoplasias colorretais; Neoplasias do colo; Adenocarcinoma; Relatos de casos

\section{INTRODUCTION}

Colorectal cancer is the fourth most common type of cancer and the second major cause of death due to cancer. In cases of colon cancer that adheres to adjacent structures, there is a local treatment failure rate of 36 to $53 \%$ following complete resection. This is more commonly seen in cases in which neighboring organs or

\footnotetext{
Study carried out at the Department of General Surgery Service of Teaching Hospital of Faculdade de Medicina do ABC - FMABC, Santo André (SP), Brazil.

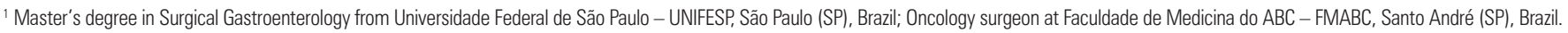

${ }^{2} \mathrm{MD}$; Department of General Surgery at Teaching Hospital of Faculdade de Medicina do ABC - FMABC, Santo André (SP), Brazil.

${ }^{3}$ Head of Department of General Surgery Service at Teaching Hospital of Faculdade de Medicina do ABC - FMABC, Santo André (SP), Brazil.

${ }^{4} \mathrm{PhD}$; Assistant professor at Faculdade de Medicina do ABC - FMABC, Santo André (SP), Brazil.

${ }^{5}$ Post-doctorate degree; Full professor of Faculdade de Medicina do ABC - FMABC, Santo André (SP), Brazil.

Corresponding author: Sergio Renato Pais Costa - Instituto de Oncologia São Paulo - Avenida Pacaembu, 1400 - CEP 01234-200 - São Paulo (SP), Brazil - Tel.: 11 3666-2299 - e-mail: sergiorenatopais@ig.com.br

Received on Nov 22, 2008 - Accepted on June 23, 2009
} 
structures are involved. When this happens, the term "locally advanced colorectal cancer" is used, referring to tumors that infiltrate or adhere to adjacent organs without distant metastases. Locally advanced colorectal cancer is frequently considered to be an incurable disease, and it represents 5 to $22 \%$ of all colorectal carcinomas $^{(1-5)}$.

Extended or multivisceral resection is the treatment of choice. The reason for performing multivisceral resection is that microscopic infiltration of the organs and/or adjacent structures cannot be ascertained preoperatively or even intraoperatively(6). Failure to identify such infiltrations may result in significantly increased local recurrence and decreased survival. In particular, all adhesions between the adenocarcinoma and neighboring organs should be assumed to be malignant and eliminated, since between 33 and $88 \%$ are malignant when histologically examined. The affected organ should be resected en bloc with a safe margin of normal tissue. Patients who undergo a marginnegative multivisceral resection present survival that is similar to that of individuals with no adjacent organ involvement, on a stage-matched basis ${ }^{(6,7)}$. Locally advanced cancer of the right colon that adheres to the proximal duodenum or head of the pancreas presents a challenge, even for skilled surgeons. This situation may require complex and difficult surgical resolution that involves en bloc pancreaticoduodenectomy plus right hemicolectomy ${ }^{(8-14)}$.

Since few reports have been published regarding this uncommon clinical situation, the present study reports on three cases of en bloc pancreaticoduodenectomy plus right hemicolectomy for locally advanced right colon cancer.

\section{CASE 1}

A 63-year-old white man was referred for evaluation of an abdominal pain with diarrhea and weight loss (12 kg over a three-month period). The patient did not present any associated disease. Physical examination revealed normal vital signs.

Upper gastrointestinal endoscopy revealed an ulcerated fungating lesion in the second portion of the duodenum that presented substenosis. Histological examination showed poorly differentiated adenocarcinoma. The upper gastrointestinal examination showed a duodenocolic fistula (Figure 1). Neither abdominal nor thoracic computed tomography scans showed any distant spreading.

Therefore, the patient underwent exploratory laparotomy, which confirmed the presence of right colon cancer (at the hepatic flexure) invading the second portion of the duodenum. Subsequently, en bloc cephalic gastroduodenopancreatectomy plus right hemicolectomy was performed. There were no intraoperative intercurrent events (Figure 2).

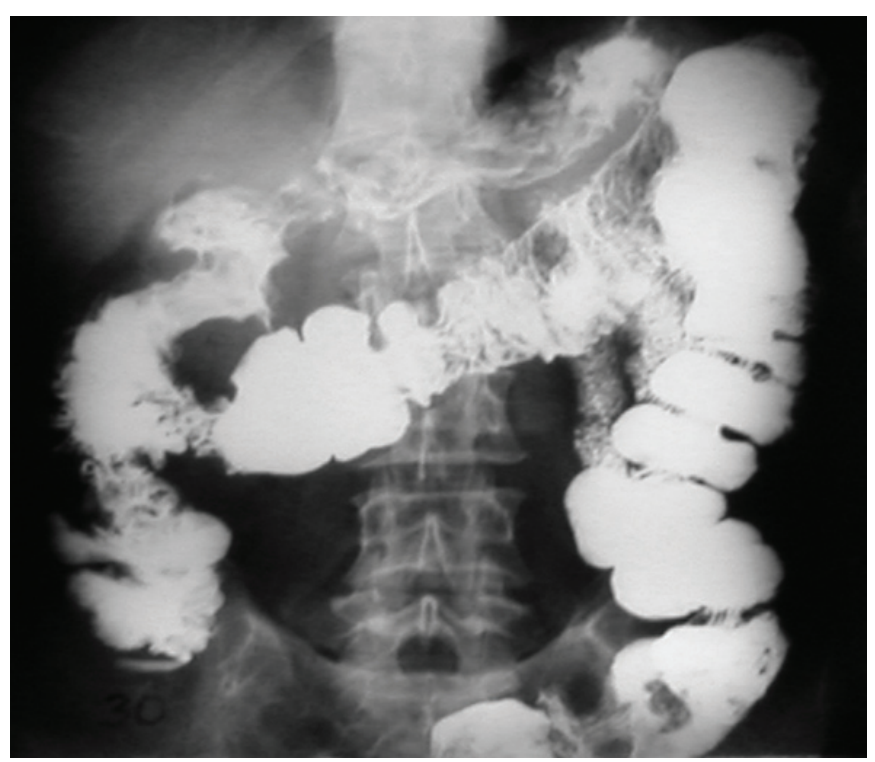

Figure 1. Image of the upper gastrointestinal tract showing duodenocolic fistula (Case 1).

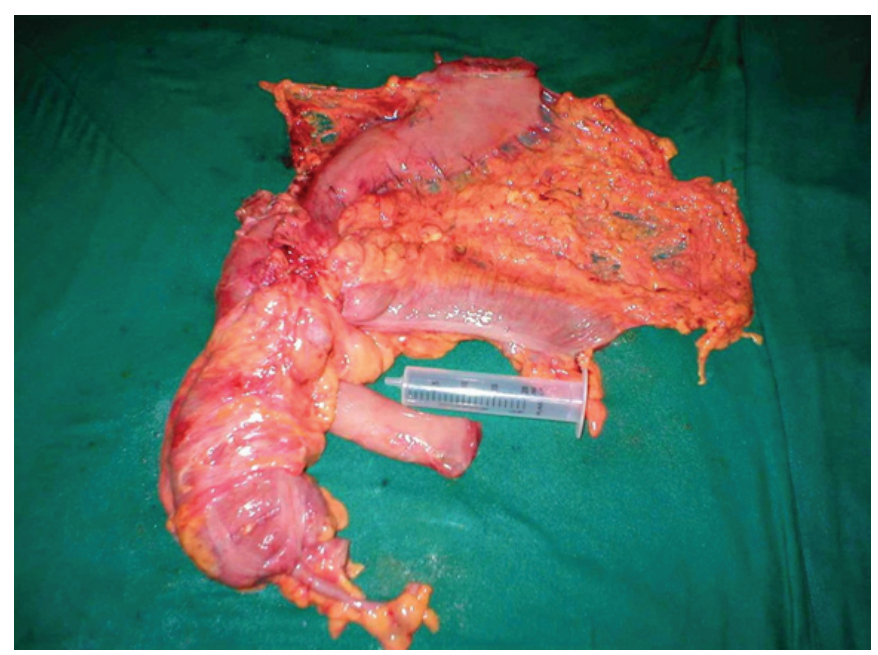

Figure 2. Surgical specimen from en bloc gastroduodenopancreatectomy plus right hemicolectomy (Case 1).

The patient presented an evisceration on the seventh postoperative day that was corrected by means of single primary closure. He was discharged on the tenth postoperative day.

The histological examination revealed a moderately differentiated adenocarcinoma in the right colon that invaded both the duodenum and the head of the pancreas, with free surgical margins. There were no lymph vessel invasion and no compromised lymph nodes (0/28). Immunohistochemical staining confirmed the colonic origin. 
The patient did not undergo any adjuvant treatment. To date, four years later, the patient remains well. There has not been any evidence of recurrence.

\section{CASE 2}

A 48-year-old black man was referred for evaluation of an abdominal mass that was associated with gastrointestinal bleeding and weight loss $(10 \mathrm{~kg}$ over a six-month period). The patient did not present with any associated disease.

Physical examination revealed a mildly tender mass in the right upper quadrant, measuring $20 \mathrm{~cm}$. Colonoscopy revealed an ulcerated lesion in the right colon (at the hepatic flexure). Histological examination showed a moderately differentiated adenocarcinoma. Neither abdominal nor thoracic computed tomography scans showed any distant spreading.

The patient underwent exploratory laparotomy, which revealed right colon cancer (at the hepatic flexure) invading the second portion of the duodenum and the right kidney. Subsequently, the patient underwent en bloc pylorus-preserving pancreaticoduodenectomy plus right hemicolectomy and nephrectomy, without any intraoperative intercurrent events.

The patient was discharged from hospital on the eighth postoperative day. There were no postoperative complications.

The histological examination revealed a moderately differentiated adenocarcinomain the rightcoloninvading the duodenum (middle portion), cephalic portion of the pancreas and right kidney. The surgical margins were disease-free. There was no lymph vessel invasion and no comprised lymph nodes (0/38). Immunohistochemical staining confirmed the colonic origin.

The patient did not undergo any adjuvant treatment. Two years later, he presented hepatic recurrence. Consequently, he underwent exploratory laparotomy but was found to present carcinomatosis and therefore hepatic resection was not performed. Subsequently, he received palliative chemotherapy. Thirty months after the multivisceral resection he finally died.

\section{CASE 3}

A 51-year-old white man was referred for evaluation of an abdominal pain and constipation that had lasted for over three months. The patient did not present with any associated disease.

Physical examination revealed a mildly tender mass in the right upper quadrant, measuring $15 \mathrm{~cm}$. Colonoscopy showed an obstructing lesion in the hepatic flexure of the right colon. Abdominal computed tomography scans showed a heterogeneous mass in which the right colon, duodenum, gallbladder and V-VI hepatic segments were involved (Figure 3). Thoracic computed tomography did not show any distant spreading.

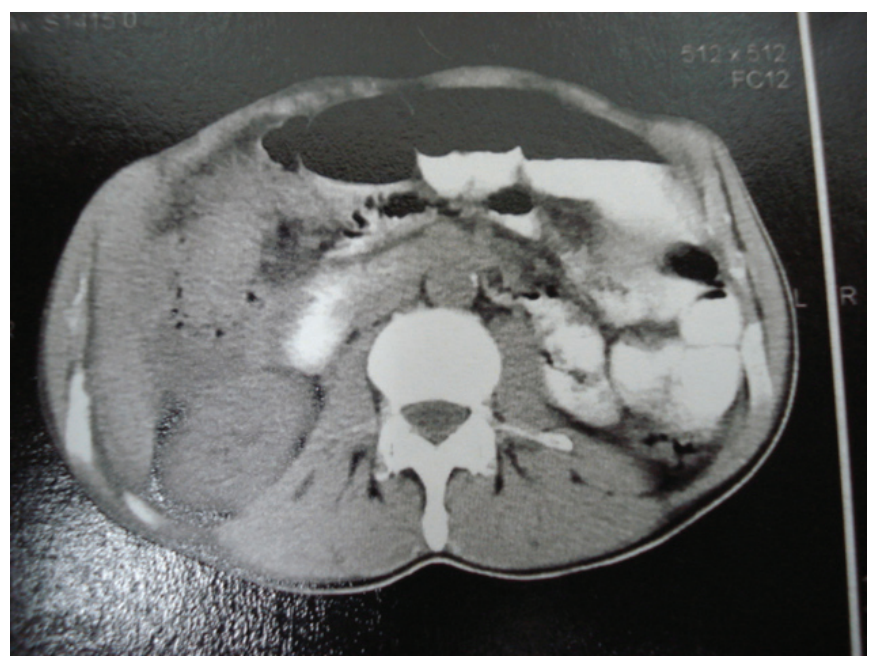

Figure 3. Computed tomography scan showing a large heterogeneous tumor in the right flexure invading the liver and second portion of the duodenum (Case 3).

The patient underwent exploratory laparotomy that revealed right colon cancer (at the hepatic flexure) invading the second portion of the duodenum, gallbladder and right lobe of the liver (IVB-V hepatic segments). Subsequently, he underwent en bloc cephalic pylorus-preserving pancreaticoduodenectomy plus right hemicolectomy and IVB-V hepatic bisegmentectomy (Figure 4).

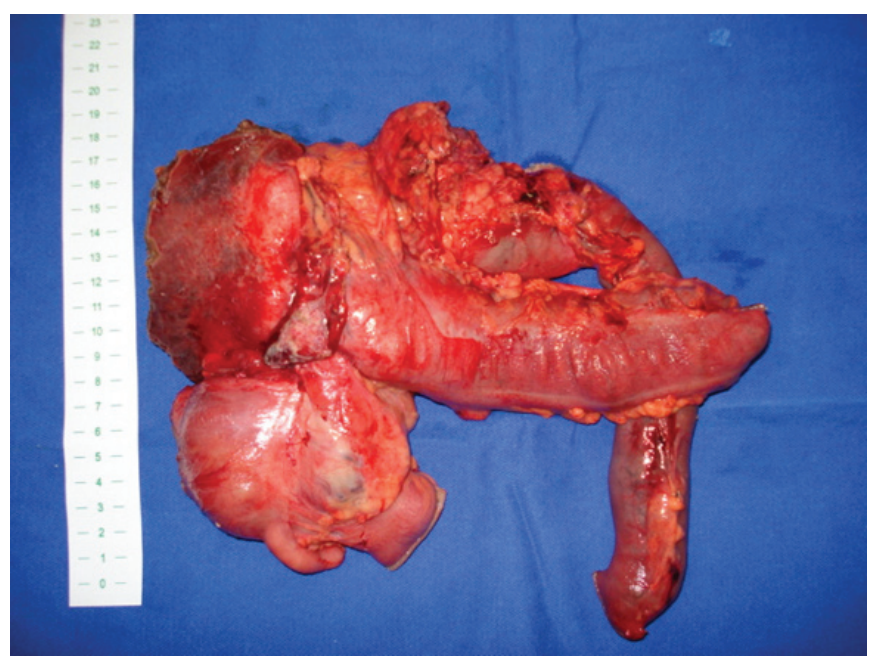

Figure 4. Surgical specimen from en bloc cephalic pylorus-preserving pancreatioduodenectomy plus right hemicolectomyand IVB-V hepatic bisegmentectomy (Case 3).

He presented a pancreatic leakage that was treated by conservative management. He was discharged from hospital on the $21^{\text {st }}$ postoperative day. 
Histological examination revealed moderately differentiated adenocarcinoma in the right colon that invaded the duodenum (middle portion, in the submucosa). The head of the pancreas and right hepatic lobe did not present any neoplastic invasion. The surgical margins were free. There was no lymph vascular invasion and no comprised lymph nodes $(0 / 33)$.

The patient did not undergo any adjuvant treatment. To date, twelve months later, the patient continues to be well. There has not been any tumor recurrence.

\section{DISCUSSION}

Locally advanced colorectal cancer is characterized by the neoplasm invading neighboring organs but not presenting any distant spreading ${ }^{(8)}$. Five to $12 \%$ of colon cancers present contiguous involvement of adjacent structures $^{(15)}$. Specifically for right colon cancer or proximal transverse colon cancer, between 11 and $28 \%$ of cases present adjacent organ invasion. Generally, the organs most invaded are the duodenum or the head of the pancreas ${ }^{(9)}$.

The first multivisceral resection of locally advanced cancer of the right colon that also involved the duodenum was described by Grey Turner, in 1929. However, it was Van Prohaska et al. who carried out the first pancreaticoduodenectomy for locally advanced right colon cancer, in $1953^{(8)}$.

Patients with locally advanced right colon cancer may have a variety of clinic conditions. The main findings that have been described are: gastrointestinal bleeding, anorexia, weight loss and diarrhea. Sometimes, diarrhea may indicate a duodenocolic fistula ${ }^{(9,10)}$.

Clinical examination may demonstrate a right upper quadrant mass, as observed in case $2^{(12)}$. Computed tomography may sometimes show a hypodense mass in which the adjacent organs are involved, as in the third case of this study ${ }^{(8,12-13)}$. More rarely, preoperative radiological examination may show no locoregional invasion, but invasion of neighboring organs is diagnosed upon intraoperative evaluation, as we observed in case 2 .

Sometimes, it may be impossible to determine whether the adherences are malignant or benign ${ }^{(8)}$. Approximately $40 \%$ of tumors present adherences to underlying structures, which are not tumoral but inflammatory adherences. Nonetheless, multivisceral resection must still be performed because separation of neoplastic lesions from adjacent invaded organs leaves local recurrence in $100 \%$ of cases ${ }^{(11)}$.

Multivisceral resection must be restricted to patients in good clinical conditions who do not present any distant spreading. The overall mortality rate following multivisceral resection of locally advanced colorectal cancer has ranged from 0 to $20.8 \%$. Although such mortality has decreased over recent years, the overall morbidity rate remains high, ranging from 20 to $70 \%{ }^{(15-19)}$.

Multivisceralresection oflocallyadvanced colorectal cancer may generally offer long-term survival. Following R0 multivisceral resection, the mean survival has been found to be around 40 months, while the overall fiveyear survival rate is close to $50 \%{ }^{(10,16,19)}$. Specifically in cases of T4 right colon cancer that undergo extended resection with pancreaticoduodenectomy, the median disease-free period may reach 54 months $^{(14)}$. On the other hand, when patients undergo palliative bypass, the mean survival period is nine months and, in cases of incomplete resection (R1-2), the mean length of survival is 11 months $^{(10)}$. Poor results from palliative surgery have also been found in our country. According to Vieira et al. ${ }^{(18)}$, the mean length of survival was 3.1 months for patients who underwent palliative procedures in Brazil.

This long-term survival following multivisceral resection may be explained by the fact that $45 \%$ of cases of locally advanced colorectal cancer do not present any compromised lymph nodes (N0), as we found in our two cases ${ }^{(11,16)}$. This hypothesis is favored by the fact that there is a specific subgroup of locally aggressive tumors. Likewise Curley et al. ${ }^{(9)}$, in the present study it was observed that locally aggressive behavior could be observed in $\mathrm{T} 4$ right colon cancers. In this series, the incidence of compromised lymph nodes was nil, which shows that the spreading was solitary and local.

The literature review showed that multivisceral resection should be the therapeutic choice in cases of locally advanced colon cancer without distant metastasis, provided that the patient presents good clinical status. Even en bloc pancreaticoduodenectomy should sometimes be performed aiming at achieve free $\operatorname{margins}^{(6-14)}$.

Adjuvant chemotherapy for locally invasive tumors is of uncertain merit. This approach is advantageous for patients who present compromised lymph nodes, but its effectiveness seems doubtful for node-negative $\mathrm{T} 3$ or $\mathrm{T} 4^{(10)}$.

\section{CONCLUSIONS}

En bloc multivisceral resection such as pancreaticoduodenectomy plus right hemicolectomy for cases of locally advanced right colon cancer may offer long-term survival in selected cases. This approach also achieves good quality of life for patients with T4 right colon cancer. On the other hand, this formidable surgical procedure should be reserved for patients with low surgical risk who do not present any systemic disease. 


\section{Despite its high morbidity, multivisceral resection alone may provide long-term survival or even cure.}

\section{REFERENCES}

1. Hunter JA, Ryan JA Jr, Schultz P. En bloc resection of colon cancer adherent to other organs. Am J Surg. 1987;154(1):67-71.

2. McGlone TP, Bernie WA, Elliott DW. Survival following extended operations for extracolonic invasion by colon cancer. Arch Surg. 1982;117(5): 595-9.

3. Pittam MR, Thornton $H$, Ellis $H$. Survival after extended resection for locally advanced carcinomas of the colon and rectum. Ann R Coll Surg Engl. 1984;66(2):81-4.

4. Heslov SF, Frost DB. Extended resection for primary colorectal carcinoma involving adjacent organs or structures. Cancer. 1988;62(8):1637-40.

5. Eisenberg SB, Kraybill WG, Lopez MJ. Long-term results of surgical resection of locally advanced colorectal carcinoma. Surgery. 1990;108(4):785-6.

6. Chang GJ, Feig BW. Cancer of the colon, rectum, and anus. In: Feig BW, Berger DH, Fuhrman GM, editors. The M.D. Anderson surgical oncology handbook. 4th ed. Philadelphia: Lippincott Williams \& Wilkins; 2006. p. 261-319.

7. Gebhardt C, Meyer W, Ruckriegel S, Meier U. Multivisceral resection of advanced colorectal carcinoma. Langenbecks Arch Surg. 1999;384(2):194-9.

8. Perez RO, Coser RB, Kiss DR, Iwashita RA, Jukemura J, Cunha JE, et al. Combined resection of the duodenum and pancreas for locally advanced colon cancer. Curr Surg. 2005;62(6):613-7.

9. Curley SA, Evans DB, Ames FC. Resection for cure carcinoma of the colon directly invading the duodenum or pancreatic head. J Am Coll Surg. 1994;179(5):587-92.
10. Koea JB, Conlon K, Paty PB, Guillem JG, Cohen AM. Pancreatic or duodenal resection or both for advanced carcinoma of the right colon: is it justified? Dis Colon Rectum. 2000;43(4):460-5.

11. Berrospi F, Celis J, Ruiz E, Payet E. En bloc pancreaticoduodenectomy for right colon cancer invading adjacent organs. J Surg Oncol. 2002;79(3):194-7.

12. Izumi Y, Ueki T, Naritomi G, Akashi Y, Miyoshi A, Fukuda T. Malignant duodenocolic fistula: report of a case and considerations for operative management. Surg Today. 1993;23(10):920-5.

13. Yoshimi F, Asato $Y$, Kuroki $Y$, Shioyama $Y$, Hori $M$, Itabashi $M$, et al. Pancreatoduodenectomy for locally advanced or recurrent colon cancer: report of two cases. Surg Today. 1999;29(9):906-10.

14. Kapoor S, Das B, Pal S, Sahni P, Chattopadhyay TK. En bloc resection of rightsided colonic adenocarcinoma with adjacent organ invasion. Int J Colorectal Dis. 2006;21(3):265-8.

15. Taylor WE, Donohue JH, Gunderson LL, Nelson H, Nagorney DM, Devine RM, et al. The Mayo Clinic experience with multimodality treatment of locally advanced or recurrent colon cancer. Ann Surg Oncol. 2002;9(2):177-85.

16. Ike H, Shimada H, Yamaguchi S, Ichikawa Y, Fujii S, Ohki S. Outcome of total pelvic exenteration for primary rectal cancer. Dis Colon Rectum. 2003;46(4):474-80.

17. Moutardier V, Turrini O, Lelong B, Hardwigsen J, Houvenaeghel G, Le Treut YP, et al. High incidence of colic anastomotic leakage complicating upper abdominal en bloc evisceration for cancer: a 47-patient series. Hepatogastroenterology. 2003;50(50):357-61.

18. Vieira RA, Lopes A, Almeida PA, Rossi BM, Nakagawa WT, Ferreira FO, et al. Prognostic factors in locally advanced colon cancer treated by extended resection. Rev Hosp Clin Fac Med Sao Paulo. 2004;59(6):361-8.

19. Lehnert T, Methner M, Pollok A, Schaible A, Hinz U, Herfarth C. Multivisceral resection for locally advanced primary colon and rectal cancer: an analysis of prognostic factors in 201 patients. Ann Surg. 2002;235(2):217-25. 